\title{
Analisis Sosial Ekonomi dalam Pemanfaatan Fasilitas Kesehatan untuk Berobat Jalan di Provinsi Jawa Barat : Analisis Data Susenas Tahun 2017
}

\author{
Social Economic Analysis in Utilizing Health Facilities for Outpatient \\ Treatment in West Java Province : Susenas Data Analysis, 2017
}

\author{
Fairuz Rabbaniyah', Mardiati Nadjib ${ }^{2}$ \\ Fakultas Kesehatan Masyarakat, Universitas Indonesia, Depok, Indonesia \\ (rabbaniyaholic@gmail.com)
}

\begin{abstract}
ABSTRAK
Pada tahun 2008-2014 pemanfaatan fasilitas kesehatan untuk berobat jalan di Indonesia mengalami penurunan. Menurut data BPS, pada tahun 2008 pemanfaatan fasilitas kesehatan untuk berobat jalan sebesar 33,4\%, pada tahun 2012 sebesar 30\% dan pada tahun 2014 sebesar 27,1\%. Tujuan penelitian ini adalah untuk mengetahui faktor sosial ekonomi yang mempengaruhi pemanfaatan fasilitas kesehatan untuk berobat jalan di Provinsi Jawa Barat. Penelitian ini menggunakan data sekunder, yaitu data Survei Sosial Ekonomi Nasional (Susenas) tahun 2017. Responden penelitiaan adalah 22.955 kepala rumah tangga di Provinsi Jawa Barat. Metode yang digunakan dalam penelitian ini menggunakan pendekatan ekonometrika dengan menggunakan metode $\mathrm{Bi}$ nary Regression, yaitu dengan model logit dan model probit. Hasil penelitian ini didapatkan bahwa faktor pendapatan dan status pekerjaan kepala rumah tangga mempengaruhi secara positif dilihat dari nilai koefisien. Pendapatan dan status pekerjaan kepala rumah tangga berpengaruh secara signifikan terhadap pemanfaatan fasilitas kesehatan. Nilai $p$-value untuk pendapatan adalah 0,001 ( $p$-value $<0,05)$, sedangkan $p$-value untuk status pekerjaan adalah 0,08 ( $p$-value $<0,1)$. Faktor-faktor sosial ekonomi yang mempengaruhi pemanfaatan fasilitas kesehatan di Provinsi Jawa Barat adalah pendapatan dan status pekerjaan kepala rumah tangga.
\end{abstract}

Kata kunci : Utilitas, sosial, ekonomi, pendapatan, pekerjaan

\section{ABSTRACT}

In 2008-2014 the utilization of health facilities for medical treatment in Indonesia has decreased. According to BPS data, in 2008 the utilization of health facilities for outpatient treatment was $33.4 \%$, in 2012 it was $30 \%$ and in 2014 it was $27.1 \%$. The purpose of this study was to determine the socio-economic factors that influence the utilization of health facilities for outpatient treatment in West Java Province. This study uses secondary data, namely data from the National Socio-Economic Survey (Susenas) in 2017. The research respondents were 22,955 heads of households in West Java Province. The method used in this study uses the econometric approach using the Binary Regression method, namely the logit model and probit model. The results of this study found that income factors and employment status of household heads positively influence the views of coefficient values. The income and employment status of the head of the household significantly influence the utilization of health facilities. The value of p-value for income is 0.001 ( $p$-value <0.05), while the p-value for employment status is 0.08 (p-value $<0.1)$. Socio-economic factors that influence the utilization of health facilities in West Java Province are income and employment status of the head of the household.

Keywords : Utilities, social, economy, income, employment 


\section{PENDAHULUAN}

Fasilitas kesehatan merupakan fasilitas yang menyediakan pelayanan kesehatan yang digunakan untuk menyelenggarakan upaya pelayanana kesehatan perorangan, baik promotif, preventif, kuratif dan rehabilitatif yang dilakukan oleh pemerintah, pemerintah daerah dan masyarakat. Fasilitas kesehatan terdiri dari dua, yaitu pelayanan kesehatan tingkat pertama dan pelayanan kesehatan rujukan tingkat lanjutan. Fasilitas kesehatan tingkat pertama berupa puskesmas, praktik dokter, praktik dokter gigi, klinik pratama dan rumah sakit kelas D pratama, sedangkan fasilitas kesehatan rujukan tingkat lanjutan berupa klinik utama, rumah sakit umum dan rumah sakit khusus. ${ }^{1}$

Pemanfaatan fasilitas kesehatan untuk berobat jalan di Indonesia mengalami pasang surut. Pada tahun 2008-2014 mengalami penurunan. Menurut data BPS, pada tahun 2008 pemanfaatan fasilitas kesehatan untuk berobat jalan sebesar 33,4\%, pada tahun 2012 sebesar 30\% dan pada tahun 2014 sebesar 27,1\%. ${ }^{2}$ Pada tahun 2016 jumlah puskesmas di Indonesia sebanyak 9767, yang terdiri dari 3.411 puskesmas rawat inap dan 6.356 puskesmas non-rawat inap. Pada tahun 2016 Provinsi Jawa Barat merupakan salah satu provinsi yang memiliki jumlah rumah sakit terbanyak di Indonesia, yaitu sebanyak 328 rumah sakit yang terdiri 254 rumah sakit umum dan 74 rumah sakit khusus. $^{3}$

Tahun 2016 Provinsi Jawa Barat memiliki jumlah penduduk sebanyak 47.379 .389 orang. ${ }^{3}$ Pada tahun 2016 Provinsi Jawa Barat memiliki jumlah puskesmas paling banyak di Indonesia, yaitu sebanyak 1.050 puskesamas yang terdiri dari 176 puskesmas rawat inap dan 874 puskesmas non-rawat inap. Provinsi Jawa Barat memiliki posyandu sebanyak 51.035. Jumlah rumah sakit di Provinsi Jawa Barat sebanyak 328 rumah sakit terdiri dari 254 rumah sakit umum dan 74 rumah sakit khusus. Provinsi Jawa Barat memiliki pelayanan kesehatan dasar lainnya sebanyak 10.201 terdiri dari balai pengobatan atau klinik, praktek perorangan dokter umum, praktek perorangan dokter gigi dan praktek perorangan bidan.

Menurut Amardeep T et al., yang mengutip pendapat Andersen perihal pengambilan keputusan untuk menggunakan pelayanan kesehatan itu terdapat tiga komponen, yaitu komponen pre- disposisi, komponen enabling (pendukung) dan komponen need. Pertama komponen predisposisi terdiri dari usia, struktur sosial, jarak dan kepercayaan kesehatan individu. Kedua komponen enabling, yaitu terdiri dari kemampuan sumber daya keluarga, seperti penghasilan keluarga, kemampuan membeli jasa pelayanan kesehatan dan keikutsertaan dalam asuransi kesehatan. Ketiga komponen need, yaitu komponen yang secara langsung berpengaruh terhadap pemilihan pelayanan kesehatan. ${ }^{5}$ Berdasarkan penelitian sebelumnya menunjukkan terdapat hubungan antara pendapatan terhadap pemanfaatan fasilitas kesehatan. ${ }^{6}$

Semakin terus bertambahnya jumlah penduduk di Jawa Barat dan banyaknya fasilitas kesehatan yang tersedia serta belum pernah ada penelitian mengenai pemanfaatan fasilitas kesehatan untuk berobat jalan di Provinsi Jawa Barat. Oleh karena itu Penulis ingin mengetahui faktorfaktor sosial ekonomi yang mempengaruhi pemanfaatan fasilitas kesehatan untuk berobat jalan di Provinsi Jawa Barat.

\section{BAHAN DAN METODE}

Desain penelitian ini adalah cross sectional $s t u d y$. Jenis data yang digunakan dalam penelitian ini adalah data sekunder Survei Sosial Ekonomi Nasional (Susenas) tahun 2017. Populasi Susenas 2017 yang digunakan adalah Provinsi Jawa Barat yang terdiri dari 27 kabupaten/kota. Sampel yang digunakan dalam penelitian ini adalah seluruh kepala rumah tangga di Provinsi Jawa Barat sebanyak 22.955. Data dianalisis secara univariat, bivariat, dan multivariat dengan menggunakan pendekatan secara ekonometrika dengan metode Binary Regression, yaitu dengan menggunakan model logit dan probit. Analisis menggunakan aplikasi Stata 15.0.

\section{HASIL}

Jumlah responden pada penelitian ini adalah 22.955 kepala rumah tangga di Provinsi Jawa Barat. Hasil uji univariat kepala rumah tangga paling banyak berusia lebih dari 45 tahun yaitu $12.695(55,3 \%)$ sedangkan paling rendah adalah kepala rumah tangga yang berusia kurang dari sama dengan 25 tahun yaitu 784 (3,42\%). Kepala rumah tangga paling banyak memiliki tingkat 
Tabel 1. Distribusi Sosiodemografi dan Ekonomi Responden di Provinsi Jawa Barat

\begin{tabular}{lcc}
\hline \multicolumn{1}{c}{ Variabel } & $\mathbf{n = 2 2 . 9 5 5}$ & $\mathbf{\%}$ \\
\hline Usia & & \\
$\quad$ Remaja & 784 & 3,42 \\
$\quad$ Dewasa & 9.476 & 41,28 \\
$\quad$ Lansia & 12.695 & 55,30 \\
Pendidikan & & \\
$\quad$ Rendah & 15.266 & 66,5 \\
$\quad$ Tinggi & 7.689 & 33,5 \\
Status pekerjaan & & \\
$\quad$ Tidak bekerja & 3.521 & 15,34 \\
$\quad$ Bekerja & 19.434 & 84,66 \\
Asuransi & & \\
Tidak punya & 8.861 & 38,6 \\
$\quad$ PBI & 5.829 & 25,39 \\
$\quad$ Non-PBI & 4.448 & 19,38 \\
Jamkesda & 1.975 & 8,6 \\
$\quad$ Kantor/Perusahaan & 1.497 & 6,52 \\
$\quad$ Swasta & 345 & 1,5 \\
Pendapatan (quintil) & & \\
$\quad$ Sangat rendah & 4.999 & 21,78 \\
$\quad$ Rendah & 4.775 & 20,80 \\
$\quad$ Menengah & 4.487 & 19,55 \\
$\quad$ Tinggi & 4.366 & 19,02 \\
$\quad$ Sangat tinggi & 4.328 & 18,85 \\
\hline
\end{tabular}

Sumber: Survei Sosial Ekonomi Nasional, 2017

pendidikan yang rendah yaitu $15.266(66,5 \%)$ sedangkan kepala rumah tangga dengan pendidikan tinggi sebanyak 7.689 (33,5\%). Status pekerjaan kepala rumah tangga paling banyak adalah bekerja yaitu sebanyak 19.434 (84,66\%), sedangkan kepala rumah tangga yang tidak bekerja sebanyak 3.521 (15,34\%). Berdasarkan kepemilikan jaminan kesehatan atau asuransi kesehatan, kepala rumah tangga yang memiliki asuransi kesehatan sebanyak $14.094 \quad(61,4 \%)$, sedangkan kepala rumah tangga yang tidak memiliki asuransi keseahatan sebanyak 8.861 $(38,4 \%)$. Dari 14.094 kepala rumah tangga yang memiliki jaminan kesehatan atau asuransi kesehatan, sebanyak 5.829 kepala rumah tangga memiliki Jaminan Kesehatan Nasional (JKN) dalam kategori Penerima Bantuan Iuran (PBI), sebanyak 4.448 kepala keluarga memiliki JKN dalam kategori non-PBI, sebanyak 1,975 kepala rumah tangga memiliki jaminan kesehatan daerah (Jamkesda), sebanyak 1.497 kepala rumah tangga yang memiliki jaminan kesehatan yang berasal dari perusahaan tempat bekerja dan sebanyak 345 kepala rumah tangga memiliki jaminan kesehatan dari pihak swasta. Berdasarkan pendapatan, paling banyak kepala rumah tangga memiliki pendapatan yang sangat rendah yaitu sebanyak 4.999 $(21,78 \%)$, sedangkan kepala rumah tangga yang memiliki pendapatan yang sangat tinggi adalah 4.328 (18,85\%) (Tabel 1).

Analisis tabulasi silang hasil analisis bivariat antara variabel independen dengan variabel dependen pemanfaatan fasilitas kesehatan diketahui bahwa kepala rumah tangga paling banyak yang berkunjung ke fasilitas kesehatan untuk berobat jalan adalah pada usia lansia, yaitu sebesar $12.666(55,3 \%)$ dibandingkan dengan usia dewasa sebesar 9.461(41,3\%) dan usia remaja sebesar 782(3,4\%). Persentase pendidikan kepala rumah tangga yang berkunjung ke fasilitas kesehatan untuk berobat jalan paling tinggi adalah kepala rumah tangga yang memiliki tingkat pendidikan yang rendah, yaitu sebesar 15.277 (66,5\%) dibandingkan dengan kepala rumah tangga yang memiliki tingkat pendidikan yang tinggi sebesar 7.682 (33,5\%). Persentase status pekerjaan kepala rumah yang berkunjung ke fasilitas kesehatan yang paling tinggi adalah kepala rumah tangga yang bekerja, yaitu sebesar 19.401 (84,7\%) dibanding-

Tabel 2. Determinan Pemanfaatan Fasilitas Kesehatan di Provinsi Jawa Barat

\begin{tabular}{lcc}
\hline \multicolumn{1}{c}{ Variabel } & $\mathbf{n}$ & $\mathbf{\%}$ \\
\hline Usia & & \\
$\quad$ Remaja & 782 & 3,4 \\
$\quad$ Dewasa & 9.461 & 41,3 \\
$\quad$ Lansia & 12,666 & 55,3 \\
Pendidikan & & \\
$\quad$ Rendah & 15.227 & 66,5 \\
$\quad$ Tinggi & 7,682 & 33,5 \\
Status pekerjaan & & \\
$\quad$ Tidak bekerja & 3.508 & 15,3 \\
$\quad$ Bekerja & 19,401 & 84,7 \\
Asuransi & & \\
$\quad$ Tidak punya & 8.843 & 38,6 \\
$\quad$ Punya & 14.066 & 61,4 \\
Pendapatan (quintil) & & \\
$\quad$ Sangat rendah & 4.979 & 21,7 \\
$\quad$ Rendah & 4.761 & 20,8 \\
$\quad$ Menengah & 4.483 & 19,6 \\
$\quad$ Tinggi & 4.360 & 19,1 \\
$\quad$ Sangat tinggi & 4.326 & 18,8 \\
\hline
\end{tabular}

Sumber: Survei Sosial Ekonomi Nasional, 2017 
Tabel 3. Perbandingan Hasil Uji Asumsi LPM, Logit dan Probit Variabel Pemanfaatan Fasilitas Kesehatan terhadap Variabel Independen

\begin{tabular}{lccccc}
\hline \multirow{4}{*}{ Variabel } & LPM(OLS) & \multicolumn{2}{c}{ Logit (MLE) } & \multicolumn{2}{c}{ Probit (MLE) } \\
\cline { 2 - 6 } & $\begin{array}{c}\text { Koefisien } \\
\text { (Robust) }\end{array}$ & $\begin{array}{c}\text { Koefisien } \\
\text { (Robust) }\end{array}$ & $\begin{array}{c}\text { Marginal } \\
\text { Effect }\end{array}$ & $\begin{array}{c}\text { Koefisien } \\
\text { (Robust) }\end{array}$ & $\begin{array}{c}\text { Marginal } \\
\text { Effect }\end{array}$ \\
\hline Usia & -0.000 & 0.162 & 0,0000 & 0.065 & 0,0001 \\
Pendidikan & $(0.001)$ & $(0.430)$ & $(0,0004)$ & $(0.131)$ & $(0,0004)$ \\
& 0.001 & 0.402 & 0,0007 & 0.128 & 0,0007 \\
Status pekerjaan & $(0.001)$ & $(0.524)$ & $(0,0005)$ & $(0.158)$ & $(0,0005)$ \\
& $0.002^{*}$ & $0.611^{*}$ & 0,0012 & $0.194^{*}$ & 0,0012 \\
Asuransi & $(0.001)$ & $(0.352)$ & $(0,0008)$ & $(0.115)$ & $(0,0008)$ \\
& -0.000 & -0.362 & $-0,0001$ & -0.114 & $-0,0001$ \\
Pendapatan & $(0.001)$ & $(0.372)$ & $(0,0004)$ & $(0.116)$ & $(0,0004)$ \\
& $0.001^{* * *}$ & $0.301^{* *}$ & 0,0006 & $0.093^{* *}$ & 0,0006 \\
Constant & $(0.000)$ & $(0.146)$ & $(0,0001)$ & $(0.043)$ & $(0,0001)$ \\
& $0.994^{* * *}$ & $4.804^{* * *}$ & --- & $2.398^{* * *}$ & --- \\
Observation & $(0.002)$ & $(0.940)$ & --- & $(0.301)$ & --- \\
Pseudo R-Squared & 22.955 & 22.955 & --- & 22.955 & --- \\
Correctly Classified & 0,001 & 0,000 & --- & 0,000 & --- \\
Hosmer-Lemeshow Chi sq & --- & 58,89 & --- & 58,69 & \\
P Chi square & -- & 0,9481 & -- & 0,9618 & --- \\
Log Likelihood & --- & 0,000 & --- & 0,000 & --- \\
SEd & --- & -1560 & --- & -1560 & -- \\
\hline
\end{tabular}

Standard errors in parentheses

${ }^{* * *} \mathrm{p}<0,01,{ }^{* *} \mathrm{p}<0,05,{ }^{*} \mathrm{p}<0,1$

kan dengan kepala rumah tangga yang tidak bekerja sebesar $3.508(15,3 \%)$ (Tabel 2).

Berdasarkan kepemilikan jaminan kesehatan atau asuransi keseahatan kepala rumah tangga, paling tinggi kepala rumah tangga yang berkunjung ke fasilitas kesehatan untuk berobat jalan adalah kepala rumah tangga yang memiliki asuransi kesehatan, yaitu sebesar $14.066(61,4 \%)$ dibandingkan kepala rumah tangga yang tidak memiliki asuransi kesehatan sebesar $8.843(38,6 \%)$. Kepala rumah tangga yang memiliki pendapatan sangat rendah paling banyak yang berkunjung ke fasilitas kesehatan untuk berobat jalan, yaitu sebesar 4.979 (21,7\%), sedangkan persentase kepala rumah tangga yang memiliki pendapatan rendah sebessar 4.761 (20,8\%) yang berkunjung ke fasilitas kesehatan untuk berobat jalan. Untuk kepala rumah tangga dengan pendapatan menengah sebesar $4.483(19,6 \%)$, pendapatan tinggi sebesar $4.360(19,1 \%)$ dan untuk kepala rumah tangga dengan pendapatan sangat tinggi sebesar 4.326 $(18,8 \%)$ (Tabel 2).

Analisis multivariat dilakukan untuk mengetahui kemungkinan dan hubungan antara variabel dependen dengan variabel independen. Taraf signifikansi yang digunakan dalam penelitian ini adalah $1 \%, 5 \%$ dan $10 \%$, jika terdapat $p$-value 0,01 , 0,05 dan 0,1 maka variabel independen tersebut secara signifikan mempengaruhi variabel dependen. Hasil analisa logit dan probit menunjukkan bahwa usia kepala rumah tangga yang berusia lansia memiliki kemungkinan yang lebih besar untuk memanfaatkan fasilitas kesehatan dibandiangkan usia dewasa dan remaja. Namun, usia tidak mempengaruhi terhadap pemanfaatan fasilitas kesehatan dengan nilai koefisien logit 0,162 dan probit 0,065 ( $p$-value $>0,1$ ). Tingkat pendidikan kepala rumah tangga yang tinggi memiliki kemungkinan lebih besar untuk memanfaatkan fasilitas kesehatan untuk berobat jalan, tetapi tingkat pendidikan tidak berpengaruh secara signifikan terhadap pemanfaatan fasilitas kesehatan dengan koefisien logit 0,402 dan probit 0,128 (p-value $>0,1$ ) (Tabel 3).

Variabel status pekerjaan kepala rumah tangga berpengaruh secara signifikan dengan pemanfaatan fasilitas kesehatan dengan nilai koefisien logit 0,611 dan probit 0,194 ( $p$-value $<0,1)$. 
Dapat diartikan bahwa kepala rumah tangga yang bekerja memiliki kemungkinan yang lebih besar untuk memanfaatkan fasilitas kesehatan untuk berobat jalan. Kepala rumah tangga yang memiliki asuransi kesehatan memiliki kemungkinan yang lebih kecil untuk memanfaatkan fasilitas kesehatan untuk berobat jalan, namun kepemilikan asuransi kesehatan tidak berhubungan secara signifikan dengan nilai koefisien logit $-0,362$ dan probit $-0,114$ ( $p$-value $>0,1)$. Pendapatan kepala rumah tangga berpengaruh secara signifikan terhadap pemanfaatan fasilitas kesehatan dengan koefisien logit 0,301 dan probit 0,093 (p-value $<0,01$. Dapat dikatakan bahwa semakin tinggi pendapatan kepala rumah tangga, maka semakin tinggu pula kemungkinan untuk memanfaatkan fasilitas kesehatan untuk berobat jalan (Tabel 3).

\section{PEMBAHASAN}

Sosial ekonomi merupakan faktor predisposisi dalam pemanfaatan fasilitas kesehatan, selain sosial ekonomi faktor predisposisi lainnya yang berkaitan dengan pemanfaatan fasilitas kesehatan adalah budaya, jenis kelamin dan geografis. Menurut Kriger et al., dalam Owoseni Joseph Sina et al., status sosial ekonomi merupakan konsep multidimensi. Dimensi yang terkait dengan status sosial ekonomi adalah status pekerjaan, prestasi, pendidikan, pendapatan, kemiskinan dan kekayaan. Menurut Abodurin et al., dalam Owoseni Joseph Sina et al., pemilihan fasilitas kesehatan ditentukan oleh selera individu, kepuasan pelayanan, dan kualitas perawatan yang diberikan. $^{7}$

Gambaran sosial ekonomi Provinsi Jawa Barat pada tahun 2016 sebanyak 4.224.325 $(8,95 \%)$ penduduk berada dibawah garis kemiskinan di Provinsi Jawa Barat. Sebanyak 2.497.592 penduduk miskin berada di daerah perkotaan dan sebanyak 1.726 .733 penduduk miskin berada di pedesaan. Garis kemiskinan Provinsi Jawa Barat sebesar Rp. 324.992, untuk garis kemiskinan di daerah perkotaan sebesar Rp. 325.017, sedangkan garis kemiskinan di daerah pedesaan sebesar $\mathrm{Rp}$. 324.937. ${ }^{4}$

Pemanfaatan fasilitas kesehatan untuk berobat jalan di Provinsi Jawa Barat sudah bagus. Kepala keluarga yang memanfaatkan fasilitas kesehatan kesehatan untuk berobat jalan sebesar 99,8\% dan kepala keluarga yang tidak memanfaatkan fasilitas kesehatan untuk berobat jalan sebesar $0,2 \%$. Penelitian ini memungkinkan untuk mempertahankan bahkan dapat menjadikan $100 \%$ penduduk Provinsi Jawa Barat untuk dapat memanfaatkan fasilitas kesehatan untuk berobat jalan dan dapat mengetahui faktor-faktor apa saja yang mempengaruhi pemanfaatan fasilitas kesehatan untuk berobat jalan. Hasil analisis regresi yang telah dilalukan, faktor-faktor yang mempengaruhi pemanfaatan fasilitas kesehatan adalah pendapatan dan pekerjaan.

Berdasarkan teori perilaku dalam pemilihan pelayanan kesehatan yang dikemukakan oleh Andersen terdapat tiga komponen, yaitu komponen predisposisi, komponen enabling (pendukung) dan komponen need (kebutuhan). Faktor sosial ekonomi dalam penelitian ini adalah usia, pendidikan, pendapatan, pekerjaan dan kepemilikan jaminan kesehatan. Faktor usia, pendidikan dan pekerjaan masuk kedalam komponen predisposisi, sedangkan faktor pendapatan dan kepemilikan jaminan kesehatan atau asuransi adalah komponen enabling (pendukung). ${ }^{8}$ Hal tersebut sejalan dengan penelitian yang dilakukan oleh Agum Dharma Yoga \& Bambang Sriyanto Eko Prakoso, bahwa faktor sosial ekonomi seperti pendapatan, pekerjaan dan kepemilikan jaminan kesehatan mempengaruhi dalam pemanfaatan fasilitas kesehatan. ${ }^{9}$

Beberapa faktor yang mempengaruhi dalam pemanfaatan fasilitas kesehatan adalah pendidikan dan pendapatan. ${ }^{10}$ Pendapatan kepala keluarga mempengaruhi dalam pemanfaatan fasilitas kesehatan, hal tersebut berhubungan dengan pembiayaan pelayanan kesehatan, salah satunya berhubungan penebusan obat. Kepala keluarga dengan pendapatan yang rendah, memiliki peluang yang kecil dalam memanfaatkan fasilitas kesehatan. ${ }^{11}$ Penduduk dengan pendapatan yang rendah menyebabkan penggunaan yang tidak proporsional terhadap rumah sakit, dokter dan obat-obatan di Saskatoon Kanada. ${ }^{12}$ Pada penelitian didapatkan variabel pendapatan memiliki hasil $p$-value sebesar 0,001, yang artinya terdapat hubungan antara pendapatan dengan pemanfaatan fasilitas kesehatan untuk berobat jalan di Provinsi Jawa Barat. Hal ini sejalan dengan penelitian yang dilakukan oleh Abdul Sayrifain et al., menyimpulkan terdapat 
hubungan antara pendapatan dan pemanfaatan pelayanan kesehatan. ${ }^{13}$ Berdasarkan penelitian yang dilakukan Yekti Widodo et al., menyimpulkan bahwa proses persalinan tidak aman atau tidak memanfaatkan fasilitas kesehatan dikarenakan status finansial suami yang tidak memadai. ${ }^{14}$

Pendapatan berkaitan erat dengan pekerjaan. Seseorang yang memiliki pekerjaan akan menghasilkan sebuah pendapatan untuk memenuhi kebutuhan sehari-hari. Salah satu faktor sosio-ekonomi konsumen yang mempengaruhi dalam pelayanan kesehatan adalah pekerjaan. ${ }^{13}$ Seseorang yang memiliki pekerjaan akan cenderung untuk memanfaatkan fasilitas kesehatan untuk berobat jalan, karena seseorang tersebut memiliki kemampuan dalam membiayai pelayanan kesehatan. ${ }^{15}$ Pada penelitian ini didapatkan hasil yang signifikan antara status pekerjaan dengan pemanfaatan fasilitas kesehatan untuk berobat jalan. Pada penelitian ini didapatkan hasil $p$-value sebesar 0,08 artinya $p$-value $<0,1$, sehingga terdapat hubungan antara status pekerjaan dengan pemanfaatan fasilitas kesehatan untuk berobat jalan di Provinsi Jawa Barat. Penelitian ini tidak sejalan dengan penelitian yang dilakukan oleh Jimmy Tampi et al., yang menyimpulkan bahwa status pekerjaan tidak berhubungan dengan pemanfaatan fasilitas kesehatan. ${ }^{6}$

Umur merupakan salah satu faktor yang mempengaruhi dalam pemanfaatan pelayanan kesehatan. Usia muda lebih rentan tehadap penyakit diare, infeksi dan saluran pernapasan, usia produktif cenderung terhadap kecelakaan, baik kecelakaan lalu lintas ataupun kecelakaan kerja, serta usia lansia rentan terhadap penyakit kronis, seperti jantung dan kanker. ${ }^{16}$ Semakin tua, maka semakin tinggi pemanfaatan fasilitas kesehatan. Sekitar usia 55 tahun ke atas pemanfaatan fasilitas kesehatan semakin meningkat tajam. ${ }^{17}$ Pada penelitian ini tidak didapatkan hasil yang signifikan antara usia kepala keluarga dengan pemanfaatan fasilitas kesehatan untuk berobat jalan. Dalam penelitian ini didapatkan $p$-value sebesar 0,909 artinya tidak terdapat hubungan antara usia dengan pemanfaatan fasilitas kesehatan untuk berobat jalan di Provinsi Jawa Barat. Penelitian ini sejalan dengan dengan Wahyuni yang menyatakan tidak terdapat hubungan yang signifikan antara usia dengan pemanfaatan pelayanan kesehatan. ${ }^{15}$
Pendidikan merupakan salah satu faktor yang mempengaruhi seseorang dalam memanfaatkan pelayanan kesehatan. ${ }^{18}$ Pendidikan yang dimiliki akan mempengaruhi kesadaran seseorang akan pentingnya kesehatan, sehingga seseorang akan terdorong untuk memanfaatkan pelayanan kesehatan yang tersedia. ${ }^{19}$ Pemanfaatan fasilitas kesehatan mulut pada anak-anak di Iran dipengaruhi oleh tingkat pendidikan yang dimiliki oleh ayah mereka. ${ }^{20}$ Pada penelitian ini didapatkan hasil yang tidak signifikan antara pendidikan kepala rumah tangga dengan pemanfaatan fasilitas kesehatan untuk berobat jalan. Penilitian ini tidak sesuai dengan penelitian sebelumnya yang dilakukan oleh Abdul Syarifain et al., yang menyimpulkan bahwa pendidikan memiliki hubungan terhadap pemanfaatan fasilitas kesehatan. ${ }^{13}$

Teori Andersen tentang kepemilikan asuransi kesehatan atau jaminan kesehatan menjadi salah satu faktor yang mempengaruhi dalam pemanfaatan fasilitas kesehatan. ${ }^{5}$ Kepemilikan asuransi kesehatan menjadi salah satu faktor yang meningkatkan pemanfaatan fasilitas kesehatan di Provinsi Gauteng Afrika Selatan. ${ }^{21}$ Kepemilikan jaminan kesehatan atau asuransi mempengaruhi dalam pemanfaatan fasilitas kesehatan karena jaminan kesehatan atau asuransi kesehatan dapat menjamin masyarakat dalam memperoleh manfaat dalam pemeliharaan kesehatan dan perlindungan dalam memenuhi kebutuhan dasar kesehatan. ${ }^{22}$ Pada penelitian ini didapatkan hasil yang tidak signifikan antara kepemilikan asuransi dengan pemanfaatan fasilitas kesehatan untuk berobat jalan. Penelitian ini sesuai dengan penelitian yang dilakukan oleh Anita Sulistyorini \& Purwanta yang menyimpulkan bahwa kepemilikan asuransi tidak berhubungan dengan pemanfaatan fasilitas pelayanan kesehatan. Berdasarkan hasil penelitian tersebut bahwa yang menimbulkan perbedaan pemanfaatan fasilitas kesehatan adalah biaya kesehatan, biaya kesehatan yang mahal dapat mempengaruhi terhadap pemanfaatan fasilitas keseha$\tan .^{23}$

Diketahui dari hasil analisis antara pendapatan dengan kepemilikan jaminan kesehatan atau asuransi kesehatan, didapatkan hasil bahwa dari 4.999 responden yang memiliki pendapatan sangat rendah terdapat $2.263(45,27 \%)$ yang tidak memiliki asuransi dan pada responden yang memiliki 
status rendah diketahui terdapat 2.129 (44,59\%) dari 4.775 responden yang tidak memiliki asuransi. Hal ini menjadi bahan evaluasi pemerintah Provinsi Jawa Barat, dimana pada tahun 2019 menuju jaminan kesehatan semesta (Universal Health Coverage) karena masih banyak kepala keluarga yang memiliki pendapatan sangat rendah dan rendah yang belum memiliki asuransi. Diharapkan pemerintah Provinsi Jawa Barat terus melakukan penyuluhan perihal pentingnya memiliki jaminan kesehatan atau asuransi kesehatan, agar masyarakat yang kurang mampu dapat memanfaatkan fasilitas kesehatan tanpa perlu memikirkan biaya yang dikeluarkan.

\section{KESIMPULAN DAN SARAN}

Pemanfaatan fasilitas kesehatan untuk berobat jalan di Provinsi Jawa Barat sudah bagus, yaitu $99,80 \%$. Faktor sosial ekonomi merupakan faktor predisposisi dalam pemanfaatan fasilitas kesehatan. Faktor-faktor yang berpengaruh secara signifikan dalam pemanfaatan fasilitas kesehatan untuk berobat jalan di Provinsi Jawa Barat adalah status pekerjaan dan pendapatan kepala keluarga. Hal ini menunjukkan kepala keluarga yang bekerja memiliki peluang yang besar untuk memanfaatkan fasilitas kesehatan untuk berobat jalan dan semakin tinggi pendapat kepala keluarga, maka semakin tinggi akan memanfaatkan fasilitas kesehatan untuk berobat jalan.

Saran yang diberikan kepada pemerintah Provinsi Jawa Barat, agar dilakukan pembukaan lapangan pekerjaan lebih banyak lagi untuk mencakup kepala keluarga yang belum memiliki pekerjaan, sehingga kepala keluarga memiliki pendapatan yang tetap. Kepala keluarga yang memiliki pendapatan tetap akan mampu untuk memanfaatkan fasilitas kesehatan untuk berobat jalan. Selain itu perlu dilakukan evaluasi perihal kepemilikan jaminan kesehatan atau asuransi kesehatan, karena masih banyak kepala keluarga yang belum memiliki jaminan kesehatan, karena pada tahun 2019 menjadi target Indonesia menuju jaminan kesehatan semesta.

\section{DAFTAR PUSTAKA}

1. Kemenkes RI. Peraturan Menteri Kesehatan Republik Indonesia Nomor 71 Tahun 2013 Tentang Pelayanan Kesehatan Pada Jaminan
Kesehatan Nasional. Jakarta: Kementerian Kesehatan Republik Indonesia; 2013.

2. BPS. Pemanfaatan Fasilitas Kesehatan Berobat Jalan di Puskesmas di Indonesia 19922014; 2015.

3. Kemenkes RI. Data dan Informasi Profil Kesehatan Indonesia 2016; 2016.

4. Dinkes Provinsi Jawa Barat. Profil Kesehatan.; 2016.

5. Thind A, Mohani A, Banerjee K, Hagigi F. Where to deliver? Analysis of Choice of Delivery Location from a National Survey in India. BMC Public Health. 2008;8(29):1-8.

6. Tampi ,J., Rumayar, AA., Tucunan, AAT. Hubungan Atara Pendidikan, Pendapatan dan Pekerjaan dengan Pemanfaatan Pelayanan Kesehatan di Rumah Sakit Umum Daerah Manembo-Nembo Bitung 2015. J Kesmas. 2016;5(1):12-17.

7. Sina OJ, Iyabo JL, M IA. Socio-economic Status and Utilization of Healthcare Facilities in Rural Ekiti, Nigeria. J Med Med Sci. 2014;2(1):001-043.

8. Babitsch B, Gohl D, Von Lengerke T. Rerevisiting Andersen's Behavioral Model of Health Services Use: a Systematic Review of Studies from 1998-2011. GMS PsychoSocial-Medicine. 2012;9(11):1-15.

9. Dharma YA, Eko PBS. Pemanfaatan Fasilitas Kesehatan Oleh Masyarakat Kabupaten Kulon Progo (Kasus: Kecamatan Wates dan Kecamatan Kalibawang). J Bumi Indonesia. 2018;7(3):1-12.

10. Notoadmodjo S. Promosi Kesehatan: Teori Dan Aplikasi. Jakarta: Rineka Cipta; 2010.

11. Wulandari, C., Ahmad, LOAI, Saptaputra SK. Faktor yang Berhubungan dengan Pemanfaatan Pelayanan Kesehatan Di UPTD Puskesmas Langara Kecamatan Wawoni Barat Kabupaten Konawe Kepulauan. J Ilm Mhs Kesehat Masy. 2016;1(3):1-9.

12. M Lemstra, J Mackenbach, C Neudorf, U Nannapaneni. High Health Care Utilization and Costs Associated with Lower Socioeconomic Status: Results From a Linked Dataset. Can J Public Heal. 2009;100(3): 180-183.

13. Syarifain,A., Rumayar, AA., Mandagi, CKF, Kesehatan. Hubungan Antara Pendidikan dan 
Pendapatan dengan Pemanfaatan Pelayanan Kesehatan oleh Pasien BPJS di Wilayah Kerja Puskesmas Sario Kota Manado. J Kesmas. 2017;6(4):1-7

14. Yekti Widodo, Siti Amanah, Nurmala K Pandjaitan DS. Pengaruh Faktor Sosial Ekonomi dan Budaya terhadap Perilaku Persalinan di Perdesaan Daerah Angka Kematian Ibu Rendah dan Tinggi. J Kesehatan Reproduksi. 2017;8(1):77-88.

15. Sri W. Faktor-Faktor yang Berhubungan dengan Pemanfaatan Pelayanan Kesehatan di Puskesmas Sumber Rejo Kota Balikpapan Provinsi Kalimatan Timur; 2012.

16. Notoatmodjo S. Pendidikan Dan Perilaku Kesehatan. Jakarta: Rineka Cipta; 2005.

17. CE Bird, LR Shugarman, J Lynn. Age and Gender Differences in Health Care Utilization and Spending for Medicare Beneficiaries in their Last Years of Life. J Palliat Med. 2002;5(5):705-712.
18. Dever A. Epidemiology in Health Services Management. USA: Aspen Publishers, Inc; 1984.

19. Notoatmodjo S. Ilmu Perilaku Kesehatan. Jakarta: Rineka Cipta; 2010.

20. Mohammadbeigi A, Arsangjang S, Mohammadsalehi N, Anbari Z, Ghaderi E. Educationrelated Inequity in Access and Utilization of Oral Health Care in Iran. J Fam Med Prim Care. 2015;4(1):35-38.

21. Abaerei AA, Ncayiyana J, Levin J. HealthCare Utilization and Associated Factors in Gauteng Province, South Africa. Glob Health Action. 2017;10(1):1-9.

22. UU Nomor 40 Tahun 2004. Tentang Sistem Jaminan Sosial Nasional. Pemerintah Republik Indonesia.

23. Anita Sulistyorini, Purwanta. Pemanfaatan Fasilitas Pelayanan Kesehatan Pemerintah dan Swasta di Kabupaten Sleman. J Kesehatan Masyarakat Nas. 2011;5(4):178-184. 